\title{
THE PROBLEMATIC OF LEGISLATIVE OVERSIGHT IN NIGERIA: A STUDY OF DELTA STATE
}

\author{
Kelly Bryan Ovie Ejumudo* \\ Department of Political Science. Novena University, Ogume, Nigeria \\ Francis Ayegbunam Ikenga \\ Department of Political Science, Delta State University, Abraka, Nigeria
}

*Email: profkellynovena@yahoo.com

This study examines the problematic of legislative oversight in Nigeria using Delta State as case study. Four research questions were r aised to guide the study and four null hypotheses were formulated for the study. The design of the study was descriptive survey. The population of the study comprised of 600 staff in the Delta State House of Assembly. The sample of the study consisted of 245 staff drawn from nine (9) departments using stratified and simple random techniques. The instrument used for data collection was legislative oversight questionnaire and the collated data were analyzed using mean rating and chi-square. The findings of the study revealed that there is a significant relationship between politics of trade-off and pay-off between the legislators and the executive as well as poor commitment to oversight functions by the legislators and legislative oversight in Delta State. The study equally showed that there is a significant relationship between culture of corruption as well as perceptual legislative subservience to the

The Indonesian Journal of International Clinical Legal Education DOI: https://doi.org/10.15294/ijicle.v3i2.45572

Submitted: Nov 11, 2020 Revised: Jan 30, 2021 Accepted: Feb 22, 2021 Available online at https://journal.unnes.ac.id/sju/index.php/iccle

(C) 2021 Authors. This work is licensed under a Creative Commons AttributionShareAlike 4.0 International License (CC BY-SA 4.0). All writings published in this journal are personal views of the authors and do not represent the views of this journal and the author's affiliated institutions. 


\section{Kelly Bryan Ovie Ejumundo \& Francis Ayegbunam Ikenga}

executive and legislative oversight in Delta State. The study recommended that that the legislature in Nigeria, particularly in Delta State, should be truly independent rather than operate and seen as a subservient extension of the executive arm of government, a new culture that is void of the politics of trade-off and pay-off between the legislature and the executive as well as corruption should be established. The study further recommended that the legislative institution should be allowed to develop and attain maturity as evident in the advanced democracies in a bid to produce a crop of legislators who have the capacity to execute their legislative oversight responsibilities regardless of whose ox is gored.

Keywords: Problematic, Legislative, Oversight, Nigeria and Delta State

\section{INTRODUCTION}

Globally, the oversight function of the legislature covers the activities of public institutions such as public corporations, government-owned companies, ministries, departments, agencies and significant others established by government and supported by public funds. Such instrument of surveillance and control is necessary to check the abuse of office and excesses of the government so as to enhance the performance of government and ensure good governance. The oversight function which can be performed ex-ante-during the design and implementation of a programme or policy, as well as ex-post, after its implementation is very critical to the actualization of government policies and programmes as well as the justification for the expenditure of government funds as Madue $^{1}$ rightly articulated. The oversight instrument which entails the informal and formal, watchful, strategic and structured scrutiny exercised by legislatures in respect of the implementation of laws, the application the budget, the strict observance of statutes and the constitution is therefore at the heart of discipline and accountability in governance at the multi-layered levels (local, state and national). The role of legislative oversight as a guarantee for ensuring strict public policy administration in accordance with legislative intent and a strong weapon against dictatorial tendencies has been of enormous benefit to the political system and it has encouraged international cooperation from different

1 Madue, J.G. (2015). Managing value for money in the public sector. London: Champman \& Hall. 
countries to strengthen the legislature as means of enhancing democracy in developing countries. ${ }^{2}$

In the face of the above reality, legislative oversight seems to have been constrained by sundry factors. For instance, Fashagba ${ }^{3}$ examined the extent to which the Nigerian legislature, characterized by infrequent appearances on the political scene and operating in an environment largely dominated by the executive arm, has performed its oversight role and found out that the Nigerian legislature has been incapable of effectively performing its oversight role because, in addition to constraints like executive interference, crippling internal conflict, inexperience and high rate of members turnover hampering legislative efficiency, the legislature has compromised its role. In a similar vein, Lemos $^{4}$ investigated the potential of Latin American Congresses to control their executive and compared the constitutional and statutory instruments for legislative oversight in six countries of the region and the study revealed that the Latin American legislatures have been often pictured as reactive ones, when compared to the powerful executives of the respective countries (Argentine, Bolivia, Brazil, Colombia, Peru and Venezuela).

In addition, Orji ${ }^{5}$ assessed the institutional capacity of the national assembly to effectively perform its oversight functions in Nigeria and the findings of the study showed that politics and the control of the executive over the expenditure of approved budgets have largely affected the legislative oversight system and practice in Nigeria. This study however seeks to examine the problematic of legislative oversight in Delta State with a focus on the impact of the politics of trade-off and pay-off between the legislature and the executive, poor commitment, the culture of corruption and the perceptual legislative subservience to the executive on the efficacy of legislative oversight in Delta State.

2 Coleman, D.N. (2016). Public finance: A contemporary application of theory to policy. New York: Harcourt Brace.

3 Fashagba, Y. J. (2017). Legislative oversight under the Nigerian presidential system. Journal of Legislative Studies, 15 (4), 439-459.

4 Lemos, R.T. (2014). Handbook of government budgeting. San Francisco: Jossey Bass.

5 Orji, P.N. (2015). Developing the Nigerian economy for an enduring democracy. Lagos: CSA Productions. 
Kelly Bryan Ovie Ejumundo \& Francis Ayegbunam Ikenga

\section{Statement of the Problem}

Globally, legislative oversight has become an acceptable and recognized tool for ensuring checks and balances, control over the expenditure of funds, accountability and citizenship involvement in governance. All the same, it somewhat appears that the effectiveness of legislative oversight has over the years been largely constrained by several factors. In this study, the thrust of the argument is that the efficacy of legislative oversight in Delta State is seriously affected by politics of trade-off and pay-off between the legislature and the executive, poor commitment, the culture of corruption and the perceptual legislative subservience to the executive in Delta State.

\section{Objectives of the Study}

The general objective of the study is to examine the problematic of legislative over-sight in Delta state, while the specific objectives are to:

1. Assess if there is any relationship between politics of trade-off and pay-off between the legislature and the executive and legislative oversight in Delta State.

2. Examine if there is any relationship between poor commitment to oversight functions by the legislators and legislative oversight in Delta State.

3. Assess if there is any relationship between culture of corruption and legislative oversight in Delta State.

4. To investigate if there is any relationship between perceptual legislative subservience to the executive and legislative oversight in Delta State.

\section{Research Questions}

The following research questions were raised to guide the study:

1. Is there any relationship between politics of trade-off and pay-off between the legislature and the executive and legislative oversight in Delta State?

2. Is there any relationship between poor commitment to oversight functions by the legislators and legislative oversight in Delta State?

3. Is there any relationship between culture of corruption and legislative oversight in Delta State?

4. Is there any relationship between perceptual legislative subservice to the executive and legislative oversight in Delta State? 
Kelly Bryan Ovie Ejumundo \& Francis Ayegbunam Ikenga

\section{Research Hypotheses}

The following null hypotheses were formulated for testing at the 0.05 level of significance:

1. There is no significant relationship between politics of trade-off and pay-off between the legislature and the executive and legislative oversight in Delta State.

2. There is no significant relationship between poor commitment to oversight functions by the legislators and legislative oversight in Delta State.

3. There is no significant relationship between culture of corruption and legislative oversight in Delta State.

4. There is no significant relationship between perceptual legislative subservice to the executive and legislative oversight in Delta State.

\section{EMPIRICAL AND THEORETICAL STUDIES ON LEGISLATIVE OVERSIGHT}

Gogo $0^{6}$ assessed the influence of legislative oversight on public accountability in Rivers State, Nigeria, 1999-2011. The findings of the study showed that there is a significant relationship between legislative oversight by the Rivers State House of Assembly and the exposition of the executive corruption in the State between 1999 and 2011 and that quest for re-election among legislators undermined the operation of legislative mechanisms of accountability in Rivers State within the period of study. Fashagba ${ }^{7}$ examined legislative oversight under the Nigerian presidential system and argued that the Nigerian legislature has been incapable of effectively performing its oversight role because of constraints like executive interference, crippling internal conflict, inexperience and high rate of members' turnover which hampers legislative efficiency. In a similar vein, Ana-Maria, Bastida and Benito ${ }^{8}$ explored budget transparency and legislative budgetary oversight and found out that poor transparency in the legislative oversight process negatively affected the effectiveness of legislative oversight function.

6 Gogo, J. T. (2018). Influence of legislative oversight on public accountability in rivers state, Nigeria, 1999-201. Unpublished Ph. D Thesis. Department of Political Science University of Nigeria, Nsukka, 1-227.

7 Fashagba, Y. J. (2017). Legislative oversight under the Nigerian presidential system. Journal of Legislative Studies, 15 (4), 439-459.

8 Ana-Maria, R., Bastida, F. And Benito, B. (2016). Budget Transparency And Legislative Budgetary Oversight. The America Review Of Public Administration. 46 (5), 34-47. 


\section{Kelly Bryan Ovie Ejumundo \& Francis Ayegbunam Ikenga}

Mbete $^{9}$ investigated legislative oversight and accountability in South Africa. The findings of the study revealed that the legislative institution lacks the administrative capacity to carry out oversight and accountability implementation plans and there exist poor institutional arrangements for the oversight of state institutions in South Africa. Onwe $^{10}$ also investigated the imperatives of the legislative oversight function in the Nigerian democratic system and established that the legislative organ is incapacitated from carrying out effective legislation for good governance because of inadequate autonomy and the executive usurpation of legislative powers. Ejikeme ${ }^{11}$ assessed the activities of the legislature and its effectiveness in ensuring and sustaining good governance in Nigeria and the findings showed that the legislative oversight, a critical aspect of the functions of the legislature other than law making, has been severally compromised and often misused as a hunting dog, apart from the fact that it has been reduced to an instrument for the blackmail of political opponents.

In like manner, Ewuim, Nnamdi and Eberinwa ${ }^{12}$ examined legislative oversight by Nigeria's National Assembly and good governance in the Obasanjo and Jonathan administration and the study found out that excessive executive interference largely hindered the effectiveness of the oversight function of the legislature. Amusa ${ }^{13}$ also investigated the legislative oversight function in Nigeria and the finding revealed that since 1999, the legislative body in Nigeria has been wobbling from one sleaze to another because of misuse of oversight functions thereby undermining democratic governance.

\section{METHOD}

The study employed descriptive survey design. The use of descriptive survey design was predicated on the fact that the researcher used a questionnaire to obtain information on the variables under study from the sample that was drawn from the population. The population of the study

9 Mbete, L. (2015). Internationally oversight and accountability in South Africa. Unpublished Ph.D Thesis, Department of Public Administration, Faculty of Economic and Management Sciences, University of Stellenbosch, 1-223.

10 Onwe, S. O. (2015). Imperatives of legislative oversight function in Nigerian democratic system. Research on Humanities and Social Sciences, 5 (4), 72-79.

11 Ejikeme, J. N. (2014). Legislative oversight in Nigeria: a watchdog or a hunting dog? Journal of Law, Policy and Globalization, 22 (16), 15-24.

12 Ewuim, N. C., Nnamdi, D. O and Eberinwa, O. M. (2014). Legislative oversight and good governance in Nigeria National Assembly: An analysis of Obasanjo and Jonathan's administration. Review of Public Administration and Management, 3 (6), I-14.

13 Amusa, K. O. (2013). Legislative function in Nigeria: Odyssey of hunters becoming hunted. Acta Universitatis Danubius; Juridica, 9 (2), 79-95. 
comprised of all the staff of the Delta State House of Assembly, Asaba. The total population of the Staff is six hundred (600), comprising of senior and junior staff in all the departments. Out of the six hundred staff, two hundred and forty five (245) were drawn using stratified and simple random sampling techniques. Simple random sampling technique was used to select twenty five (25) staff from seven (7) departments. While thirty five (35) staff was selected from the departments of Administration and Legislative matters simply because the two departments have the highest population. The choice of stratified is to ensure equal representation of all the nine departments. While simple random sampling technique was predicated on the fact that every staff of the department has equal chances of been selected. The instrument that was used for data collection was legislative oversight Questionnaire that contained sixteen (16) items which enabled the researcher to spread the questions/items across the independent and intervening variables. All the research hypotheses were tested for significant difference at 0.05 level of significance using Chi-Square.

\section{PRESENTATION AND DISCUSSION OF RESULTS}

\section{Research Question One:}

Is there any relationship between politics of trade-off and pay-off between the legislator and the executive and legislative oversight in Delta State?

Table 1: mean rating showing the relationship between politics of trade-off and pay-off between the legislature and the executive and legislative oversight

\begin{tabular}{llllll}
\hline S/N & A & SA & D & SD & $\bar{X}$ \\
\hline $\mathbf{1}$ & 115 & 140 & 120 & 40 & $\mathbf{1 . 7 7}$ \\
$\mathbf{2}$ & 95 & 160 & 165 & 20 & $\mathbf{1 . 4 5}$ \\
$\mathbf{3}$ & 120 & 100 & 105 & 120 & $\mathbf{1 . 8 9}$ \\
$\mathbf{4}$ & 75 & 200 & 60 & 160 & $\mathbf{2 . 1 1}$ \\
Grand mean & & & & $\mathbf{1 . 8 1}$ \\
\hline
\end{tabular}

\section{Criterion Mean $=2.5$}

Table 1 shows a grand mean of 1.89 and a criterion mean of 2.50 . Since the grand mean is less than the criterion mean, it implies that some of the respondents agreed that there is a relationship between politics of trade-off and pay-off between the legislature and the executive and the legislative oversight. Hence, it can be concluded politics of trade-off and pay-off between the legislature and the executive has hindered effective legislative oversight function in Delta State House of Assembly. 


\section{Hypothesis 1 (Ho1)}

There is no significant relationship between politics of trade-off and payoff between the legislature and the executive and legislative oversight in Delta State.

Table 2: Chi-square analysis of questionnaire for the relationship between politics of trade-off and pay-off between the legislature and the executive and legislative oversight in Delta State

\begin{tabular}{|c|c|c|c|c|c|c|c|}
\hline Items & $\mathrm{SA} / \mathrm{A}$ & $\mathrm{SD} / \mathrm{D}$ & Total & Df & $\begin{array}{l}\mathrm{X}^{2}- \\
\text { cal. }\end{array}$ & $\begin{array}{l}X^{2}- \\
\text { cri. }\end{array}$ & Decision \\
\hline 1 & 79 & 21 & 235 & \multirow{4}{*}{3} & \multirow{4}{*}{44.08} & \multirow{4}{*}{7.82} & \multirow{4}{*}{$\begin{array}{l}\text { Ho } 1 \\
\text { Rejected }\end{array}$} \\
\hline 2 & 74 & 26 & 235 & & & & \\
\hline 3 & 72 & 28 & 235 & & & & \\
\hline 4 & 74 & 26 & 235 & & & & \\
\hline
\end{tabular}

In table 2 above, with alpha level of 0.05 , the degree of freedom (DF) of 3 , the critical value is 7.82 while calculated value is 44.08 . Since the calculated value is greater than the critical value, the null hypothesis is therefore rejected. This shows that there is a significant relationship between politics of trade-off and pay-off between the legislature and executive and legislative oversight in Delta State.

\section{Research Question Two:}

Is there any relationship between poor commitment to oversight functions by the legislators and legislative oversight in Delta State?

Table 3: Mean rating showing the relationship between poor commitment to oversight functions by the legislators and legislative oversight in Delta State

\begin{tabular}{llllll}
\hline C & A & SA & D & SD & $\bar{X}$ \\
\hline 1 & 75 & 130 & 135 & 200 & $\mathbf{2 . 3 0}$ \\
\hline 2 & 90 & 140 & 105 & 160 & $\mathbf{2 . 1 1}$ \\
\hline 3 & 105 & 110 & 180 & 60 & $\mathbf{1 . 9 4}$ \\
\hline 4 & 85 & 140 & 120 & 160 & $\mathbf{2 . 1 5}$ \\
\hline \multicolumn{2}{l}{ Grand mean } & & & & $\mathbf{2 . 1 2}$ \\
\hline
\end{tabular}

Criterion Mean $=2.50$

Table 3 shows a grand mean of 2.12 and a criterion mean of 2.50 . Since the grand mean is less than the criterion mean, it implies that some of the respondents agreed that there is a relationship between poor commitment to oversight functions and the legislative oversight. Hence, it can be concluded that poor commitment to oversight functions has constrained effective legislative oversight function in Delta State House of Assembly. 


\section{Hypothesis 2 (Ho2)}

There is no significant relationship between poor commitment to oversight functions by the legislators and legislative oversight in Delta State.

Table 4: Chi-square analysis of questionnaire for the relationship between poor commitment to oversight functions by the legislators and legislative oversight in Delta State

\begin{tabular}{|c|c|c|c|c|c|c|c|}
\hline Items & SA/A & SD/D & Total & Df & $\begin{array}{l}\mathrm{X}^{2}- \\
\text { cal. }\end{array}$ & $\begin{array}{l}X^{2}- \\
\text { cri. }\end{array}$ & Decision \\
\hline 1 & 60 & 40 & 235 & \multirow{4}{*}{3} & \multirow{4}{*}{45.16} & \multirow{4}{*}{7.82} & \multirow{4}{*}{$\begin{array}{l}\mathrm{Ho}_{2} \text { is } \\
\text { Rejected }\end{array}$} \\
\hline 2 & 68 & 32 & 235 & & & & \\
\hline 3 & 68 & 32 & 235 & & & & \\
\hline 4 & 66 & 34 & 235 & & & & \\
\hline
\end{tabular}

In table 4 above, with alpha level of 0.05 , the degree of freedom (DF) of 3, the critical value is 7.82 while calculated value is 45.16 . Since the calculated value is greater than the critical value, the null hypothesis is therefore rejected. This shows that there is a significant relationship between poor commitment to oversight functions and legislative oversight in Delta State.

\section{Research Question Three:}

Is there any relationship between culture of corruption and legislative oversight in Delta State?

Table 5: Mean rating showing the culture of corruption and legislative oversight in Delta State

\begin{tabular}{llllll}
\hline S/N & A & SA & D & SD & $\bar{X}$ \\
\hline 1 & 75 & 190 & 144 & 68 & $\mathbf{2 . 0 3}$ \\
\hline 2 & 65 & 178 & 165 & 104 & $\mathbf{2 . 1 8}$ \\
\hline 3 & 80 & 182 & 120 & 96 & $\mathbf{2 . 0 3}$ \\
\hline 4 & 65 & 110 & 360 & 260 & $\mathbf{3 . 3 8}$ \\
\hline \multicolumn{2}{l}{ Grand mean } & & & & $\mathbf{2 . 4}$ \\
\hline
\end{tabular}

\section{Criterion Mean $=2.50$}

Table 5 shows a grand mean of 2.4 and a criterion mean of 2.50 . Since the grand mean is less than the criterion mean, it implies that some of the respondents agreed that there is a relationship between culture of corruption and the executive and the legislative oversight. Hence, it can be concluded culture of corruption has undermined effective legislative oversight function in Delta State House of Assembly.

\section{Hypothesis 3 ( $\left.\mathbf{H}_{3}\right)$}

There is no significant relationship between culture of corruption and legislative oversight in Delta State. 
Kelly Bryan Ovie Ejumundo \& Francis Ayegbunam Ikenga

Table 6: Chi-square analysis of questionnaire for the relationship between culture of corruption and legislative oversight

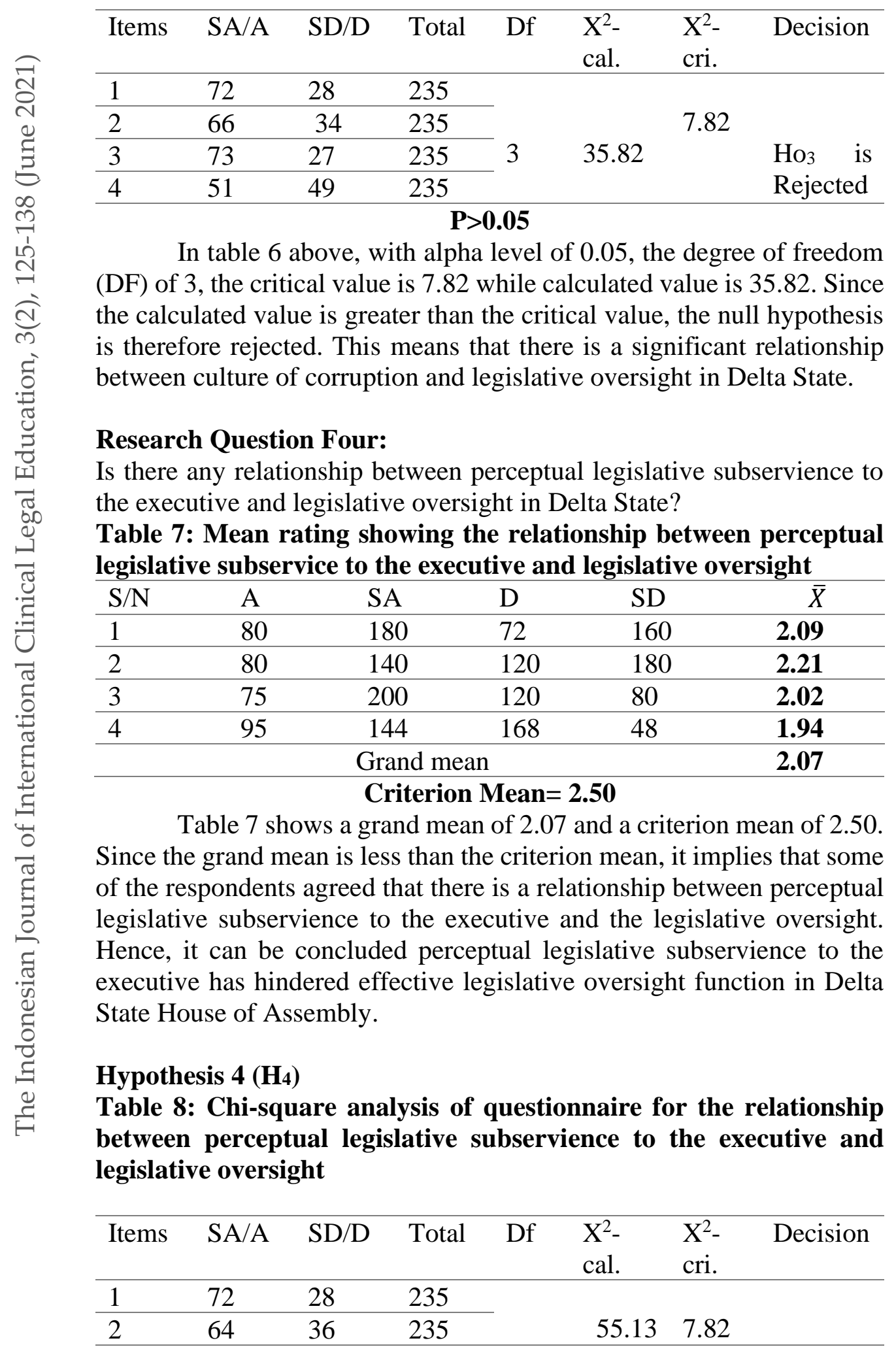


Kelly Bryan Ovie Ejumundo \& Francis Ayegbunam Ikenga

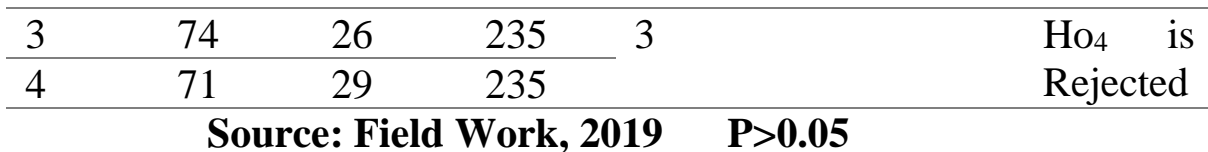

In table 8 above, with alpha level of 0.05 , the degree of freedom (DF) of 3 , the critical value is 7.82 while calculated value is 55.13 . Since the calculated value is greater than the critical value, the null hypothesis is therefore rejected. This means that there is a significant relationship between perceptual legislative subservience to the executive and legislative oversight in Delta State.

\section{DISCUSSION OF FINDINGS}

\section{A. Politics of Trade-off and Pay-off and Legislative Oversight}

The study showed that there is a significant relationship between politics of trade-off and pay-off between the legislature and the executive and legislative oversight in Delta State. This is obvious in the fact that the institution lacks an administrative unit to carry out oversight and accountability implementation plans and the parliament does not have electronic or manual systems in place for oversight function so as to ensure accountability through effective evaluation of the activities of the executives. ${ }^{14}$ The finding is also in accordance with Onwu (2015) who established that the legislative organ is incapacitated from carrying out effective legislation for good governance because of inadequate autonomy and the executive usurpation of legislative powers.

\section{B. Poor Commitment to Oversight Functions by the Legislators and Legislative Oversight}

The study equally showed that there is a significant relationship between poor commitment to oversight functions by the legislators and legislative oversight in Delta State. One plausible explanation for this finding is that the legislative body in Nigeria has been wobbling from one sleaze to another because of misuse of oversight functions thereby undermining democratic governance. ${ }^{15}$ This finding is also in synchrony with Mbete's position that so many legislators are ineffective and largely do not

14 Mbete, L. (2015). Internationally oversight and accountability in South Africa. Unpublished Ph.D Thesis, Department of Public Administration, Faculty of Economic and Management Sciences, University of Stellenbosch, 1-223.

15 Amusa, K. O. (2013). Legislative function in Nigeria: Odyssey of hunters becoming hunted. Acta Universitatis Danubius; Juridica, 9 (2), 79-95. 
understand their statutory role, function and mandate in overseeing the activities of the executive. ${ }^{16}$

\section{Culture of Corruption and Legislative Oversight}

The study lucidly revealed that there is a significant relationship between culture of corruption and legislative oversight in Delta State. This finding gives credence to Ejikeme ${ }^{17}$ who opined that the legislative oversight as a critical aspect of the functions of the legislature other than law making, has been severally compromised and often misused as a hunting dog and that the legislature has reduced this all important function to mere alarm mechanism being used to blackmail or witch-hunt political opponents, extort money from government ministries, departments and agencies.

\section{Perceptual Legislative Subservience to the Executive and Legislative Oversight}

The study equally revealed that there is a significant relationship between perceptual legislative subservience to the executive and legislative oversight in Delta State. This finding is in consonance with Fashagba ${ }^{18}$ who articulated that the Nigerian legislature has been incapable of effectively performing its oversight role because of constraints like executive interference, crippling internal conflict, inexperience and high rate of members' turnover.

\section{CONCLUSIONS AND RECOMMENDATIONS}

Based on one of the major findings of this study, that showed that there is a significant relationship between politics of trade-off and pay-off between the legislators and the executive and legislative oversight, it is concluded that politics of trade-off and pay-off between the legislators and the executive has hampered legislative oversight functions in Delta State. Equally, since there is a significant relationship between poor commitment to oversight functions by the legislators and legislative oversight, it can be inferred that poor commitment to oversight functions

16 Mbete, L. (2015). Internationally oversight and accountability in South Africa. Unpublished Ph.D Thesis, Department of Public Administration, Faculty of Economic and Management Sciences, University of Stellenbosch, 1-223.

17 Ejikeme, J. N. (2014). Legislative oversight in Nigeria: a watchdog or a hunting dog? Journal of Law, Policy and Globalization, 22 (16), 15-24.

18 Fashagba, Y. J. (2017). Legislative oversight under the Nigerian presidential system. Journal of Legislative Studies, 15 (4), 439-459. 
by the legislators has undermined legislative oversight functions in Delta State.

In a similar vein, since there is a significant relationship between culture of corruption and legislative oversight functions, the contention of the study is that the ingrained culture of corruption amongst legislators has negatively affected the legislative oversight functions in Delta State. Conclusively, since there is a significant relationship between perceptual legislative subservience to the executive and legislative oversight, it is instructive to note that perceptual legislative subservience of the Delta State legislators has constrained the legislative oversight functions in Delta State.

Sequel to the above findings and conclusions of the study, the study recommended that the legislature in Nigeria, particularly in Delta State, should be genuinely independent rather than operate and seen as a subservient extension of the executive arm of government, a new culture that is void of the politics of trade-off and pay-off between the legislature and the executive as well as corruption should be established. The study further recommended that the legislative institution should be allowed to develop and attain maturity as evident in the advanced democracies with an eye to produce a crop of legislators who have the capacity to execute their legislative oversight responsibilities regardless of whose ox is gored.

\section{REFERENCES}

Amusa, K. O. (2013). Legislative function in Nigeria: Odyssey of hunters becoming hunted. Acta Universitatis Danubius; Juridica, 9 (2), 79-95.

Ana-Maria, R., Bastida, F. and Benito, B. (2016). Budget Transparency And Legislative Budgetary Oversight. The America Review of Public Administration. 46 (5), 34-47.

Coleman, D.N. (2016). Public finance: A contemporary application of theory to policy. New York: Harcourt Brace.

Ejikeme, J. N. (2014). Legislative oversight in Nigeria: a watchdog or a hunting dog? Journal of Law, Policy and Globalization, 22 (16), $15-24$.

Ewuim, N. C., Nnamdi, D. O and Eberinwa, O. M. (2014). Legislative oversight and good governance in Nigeria National Assembly: An analysis of Obasanjo and Jonathan's administration. Review of Public Administration and Management, 3 (6), I-14.

Fashagba, Y. J. (2017). Legislative oversight under the Nigerian presidential system. Journal of Legislative Studies, 15 (4), 439459. 


\section{Kelly Bryan Ovie Ejumundo \& Francis Ayegbunam Ikenga}

Gogo, J. T. (2018). Influence of legislative oversight on public accountability in rivers state, Nigeria, 1999-201. Unpublished $P h$. $D$ Thesis. Department of Political Science University of Nigeria, Nsukka, 1-227.

Lemos, R.T. (2014). Handbook of government budgeting. San Francisco: Jossey - Bass.

Madue, J.G. (2015). Managing value for money in the public sector. London: Champman \& Hall.

Mbete, L. (2015). Internationally oversight and accountability in South Africa. Unpublished Ph.D Thesis, Department of Public Administration, Faculty of Economic and Management Sciences, University of Stellenbosch, 1-223.

Onwe, S. O. (2015). Imperatives of legislative oversight function in Nigerian democratic system. Research on Humanities and Social Sciences, 5 (4), 72-79.

Orji, P.N. (2015). Developing the Nigerian economy for an enduring democracy. Lagos: CSA Productions.

\section{Conflicting Interest Statement}

All authors declared that there is no potential conflict of interest on publishing this article.

\section{Funding}

None

Publishing Ethical and Originality Statement

All authors declared that this work is original and has never been published in any form and in any media, nor is it under consideration for publication in any journal, and all sources cited in this work refer to the basic standards of scientific citation.

Cite this article as:

Ejumudo, K. B. O., \& Ikenga, F. A. (2021). The Problematic of Legislative Oversight in Nigeria: A Study of Delta State. The Indonesian Journal of International Clinical Legal Education,3(2), 125-138. https://doi.org/10.15294/ijicle.v3i2.45572 